\title{
Listomania, Or Catalog as Technique (With Examples from Poetry and Prose, Classical and Modern, Western and Russian) ${ }^{1}$
}

\author{
Alexander Zholkovsky \\ University of Southern California \\ Los Angeles, CA, USA
}

\section{Спискомания, или Каталоги как прием (с примерами из поэзии и прозы, классической и современной, западной и русской)}

\author{
А.К. Жолковский \\ Университет Южной Калифорнии \\ Лос-Анджелес, США
}

Disclaimer: Lisztomania, a 1975 film by Ken Russell, drawn from a biography of Franz Liszt, has nothing to do with this paper and is brought up solely to justify my catchy punning title.

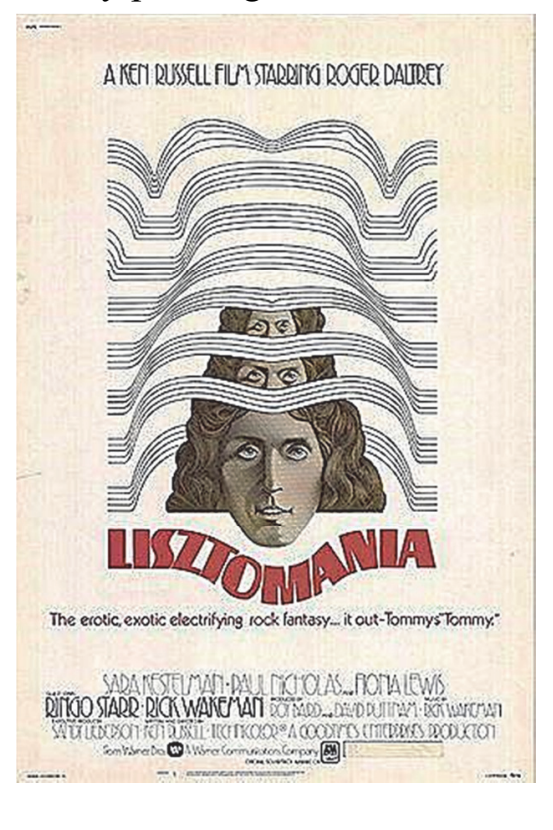

1. One of the staple quotables from Vasilii Aksenov's The Island of Crimea (Ostrov Krym, written in 1979, published 1981, English translation by Michel Heim, 1983; very much in the news as we speak in 2014) is the list of goods the protagonist Andrei Luchnikov failed to bring along to the 1970s' Moscow from Paris.

«Не купил: двойных бритвенных лезвий, цветной пленки для мини-фото, кубиков со вспышками, джазовых пластинок, пены для бритья, длинных носков, джинсов - о, Боже! — вечное советское заклятье - джинсы! - маек с надписями, беговых туфель, женских сапог, горных лыж, слуховых аппаратов, „водолазок“, лифчиков с трусиками, шерстяных колготок, костяных шпилек, свитеров из ангоры и кашмира, таблеток алка зельцер, переходников для магнитофонов,

1 An invited lecture at UC Berkeley, Monday March 31, 2014. 
бумажных салфеток, талька для припудривания укромных местечек, липкой ленты „скоч“, да и виски „скоч“, тоника, джина, вермута, чернил для ручек „паркер“ и „монблан“, кожаных курток, кассет для диктофонов, шерстяного белья, дубленок, зимних ботинок, зонтиков с кнопками, перчаток, сухих специй, кухонных календарей, тампекса для менструаций, фломастеров, цветных ниток, губной помады, аппаратов hi-fi, лака для ногтей и смывки, смывки для лака - ведь сколько уже подчеркивалось насчет смывки! - обруча для волос, противозачаточных пилюль и детского питания, презервативов и сосок для грудных, тройной вакцины для собаки, противоблошиного ошейника, газовых пистолетов, игры „Монополь“, выключателей с реостатами, кофемолок, кофеварок, задымленных очков, настенных открывалок для консервов, цветных пленок на стол, фотоаппаратов „поляроид“, огнетушителей для машины, кассетника для машины, насадки STR для моторного масла, газовых баллонов для зажигалок и самих зажигалок с пьезокристаллом, клеенки для ванны - с колечками! - часов „кварц“, галогенных фар, вязаных галстуков, журналов „Vogue“, „Playboy“, „Downbeat“،, замши, замши и чего-нибудь из жратвы...»

"Failed to buy double razor blades, color film for mini-photos, flash-bulbs, jazz records, shaving cream, long socks, jeans - Oh, God! The eternal Soviet swear word jeans! T-shirts with logos, running shoes, women's boots, downhill skis, sound systems, skivvies, bras and panties, woolen pantyhose, ivory hairpins, angora and cashmere sweaters, AlkaSeltzer tablets, power cables for tape-recorders, pa per napkins, talcum powder for secluded spots, Scotch tape and Scotch whisky, tonic, gin, vermouth, ink for Parker and Mont Blanc pens, leather jackets, Dictaphone cassettes, woolen underwear, sheepskin coats, winter boots, foldaway umbrellas, gloves, dried spices, kitchen calendars, tampons, flow-masters, colored thread, lipstick, hi-fi apparatus, nail polish and nail polish remover - how this was underlined! - hair-bands, contraceptive pills and children's food, condoms and teats for babies' bottles, triple vaccines for dogs, a flea collar, air pistols, Monopoly games, electric switches and rheostats, coffee grinders, coffee urns, dark glasses, wall-mounted can openers, colored stick-on veneers for tables, Polaroid cameras, car fire extinguishers, car cassette players, STP nozzles for auto grease, gas cylinders for cigarette lighters and piezo-electric lighters, shower curtains with rings, quartz watches, halogen headlamps, knitted ties, Vogue, Playboy, Downbeat, ssuede leather, and any kind of food he could lay his hands on."

The list is of historical and ethnographic interest but rather long, deploying as it does about 200 words and over 70 items. It is hard to read through the end, - which, of course, is not necessarily bad. The progenitor of all such catalogs, the list of Achaean ships in Canto II of the Iliad, is way longer (around 300 hexameter verses). Small wonder Osip Mandel'shtam confessed reaching only its middle.

There exists a respectable set of studies of Homeric and similar catalogs and, most recently, an impressive piece on Russian literary catalogs with special reference to the poetry of Mikhail Kuzmin by Stanislav Shvabrin (Svabrin 2011). In light of this scholarship, I was enticed to look at the traditional roots of Aksyonov's list of desirabilia.

Homer's catalog is not just a list but a list of lists, and it inventories not so much ships as the names of the commanders from different areas of Greece and the nameless soldiers led by them, whose numbers are suggested by the number of vessels.

The readability of this catalog has been debated since Aristotle, the argument hinging on the role it can be shown to play in the narrative design of the entire epic (and I'll skip this). 
Be that as it may, the catalog remains a huge chunk of static, un-emplotted material, - unlike the portrayal of Achilles' shield in Canto XVII, which was glorified by Lessing for presenting not merely a picturesque list of ornaments but rather the story of its manufacture by Hephaestus.

A history of creating - rather than a list of the created - opens the Bible (postdating the Iliad by only a couple of centuries). Heaven, earth, day, night, land, water, grass, trees and so on - all the way to man, are shown emerging in a six-stage narrative of their creation.

In Homer, unlike Mandel'shtam's very dynamic picture:

...Сей длинный выводок, сей поезд журавлиный,

Что над Элладою когда-то поднялся,

Как журавлиный клин в чужие рубежи -

На головах царей божественная пена -

Куда плывете вы? <...>

И море, и Гомер - все движется любовью <...

(Мандельштам, «Бессонница. Гомер. Тугие паруса...»),

the ships do not fly or sail, but are simply listed as having arrived.

2. To be sure, the literary value of a catalog cannot be confined to its dynamism. Inserting a catalog into a literary text is a special case of the splicing "Operation Intertext". It involves an interaction of the main, literary, text with an "alien" object: a quote from the classics, description of a painting (ekphrasis), a philosophical paradigm, a fragment of non-fiction ${ }^{2}$. The mechanism of such transplantation includes a range of options: from a mere copying of the inserted piece to its radical reformatting.

Literary appropriation of a catalog (= a specimen of nonliterary, everyday, business prose) creates tension between loyalty (naive or deliberate) to its extant parameters and their purposeful transformation. The length, order and uniformity of practical inventories are welcome in their literary versions, as they help create a semantic halo of memory and authenticity, but as a rule, they need further, fictional, "fine-tuning".

The "memory" element is well served by the very principle of itemizing, preferably exhaustive: the longer the list, the more convincing it is. In texts designed for oral performance, the mnemonic aspect plays a special role. As human memory prefers storing narratives, rather than inventories, delivering catalogical passages is much harder than retelling even complicated plots; as a result, these passages become a sort of high-wire act. They require the use of special mnemonic techniques, thus enriching the text with additional artistic patterns — semantic, narrative, spatial, phonetic etc. (Minchin 1996).

2 To be sure, in actual literary practice, the catalog that is to be "inserted" in the text is quite often not brought in "from the outside" but rather, like everything else there, is created by the author and thus is also a literary artefact. But for the sake of presentation I allow myself this oversimplification - similar to the way in narrative studies the "story" (the Russian Formalists' fabula) is often considered as "raw material" subject to compositional reworking that turns it into "discourse" (siuzhet), whereas in fact it is also a product of certain creative devices. 
As for the aura of authenticity, literary catalogs owe it to the same diligent enumeration, claiming, as it were, no artistic boldness or narrative interest. However, such a lack may conflict with the desirability of entertainment value, - a contradiction that generates a variety of artistic solutions. The linear order inherent in catalogs is quite welcome in poetic texts, as it fits naturally their "successive" format, to use Iurii Tynianov's signature formula (suktsessivnost' stikhovogo riada); it also helps with verse's mnemonic function. It is more of a problem for prose and other storytelling genres, which have had to develop multiple techniques of narrativizing their lists.

In turn, the uniformity, that is, the initial equality of listed items, potentially contradicts the task of promoting the catalog's "sponsor". There are various gradations of hierarchical orientation toward the top. For instance, Homer's ships are, of course, geared to the victory over Troy, but their list is quite extensive and thus horizontal. On the other hand, each verse of Ezekiel's biblical "Lament over Tyre" either glorifies Tyre's greatness or prophesies its fall ${ }^{3}$.

Verticality reaches its maximum in those texts where the listed items are not simply subordinated to the one at the top (as its possessions, tools or other attributes), but are its inalienable characteristics, manifestations, names. Such are the multiple names of gods and titles of monarchs, e.g.:

Титулатура Николая II:

«Император и Самодержец Всероссийский, Московский, Киевский, Владимирский, Новгородский, Царь Казанский, Царь Астраханский, Царь Польский, Царь Сибирский, Царь Херсониса Таврического, Царь Грузинский, Великий Князь Финляндский и прочая, и прочая, и прочая».

(Nicolas II, Emperor and Autocrat of all the Russias, of Moscow, Kiev...)

Scholars distinguish between simple lists and more detailed, so to speak, annotated, catalogs proper. I would also separate "real" lists/catalogs from other enumerative constructions widely used in literature. The ones I'll be focusing on are characterized by:

- countability, that is, a clear tendency to exhaust the entire set;

— use of numerals and proper names;

- mention of a written or otherwise compiled and physically existing inventory; a text";

— foregrounding of its textuality, verbal nature, i.e. its role as "a text inside

- and dialogic presentation, emphasizing the status of a list as a social document.

As we proceed to consider samples of literary catalogs, we will be paying attention to the paradoxical reconfiguration of their main parameters, that is, the way

- enumeration mutates into narrative;

- factography turns virtual and fictional;

— the horizontal becomes vertical;

- and the purely informational is textualised, so that matter-of-fact data about persons and objects begin to look like a collection of exotic appellations.

${ }^{3}$ See Ch. 27 of the Biblical Book of Ezekiel $\left(6^{\text {th }}\right.$ c. BCE), another early and influential specimen of catalogical (cum naval) discourse. 
3. Among Russian classics, Gogol is known for having styled himself as a Homer. Taras Bulba, his attempt at a national epic, abounds in catalog sequences, whose memorial character is often emphasized by the motif of death in battle.

In Dead Souls, some catalog passages sound quasi-Homeric, for instance the list of Sobakevich's dead serfs in Chapter V.

«- Вот, например, каретник Михеев! ведь больше никаких экипажей и не делал, как только рессорные <... [П]рочность такая, сам и обобьет, и лаком покроет! <..> А Пробка Степан, плотник? я голову прозакладую, если вы где сыщете такого мужика <...> Служи он в гвардии, ему бы Бог знает что дали, трех аршин с вершком ростом! <...> Милушкин, кирпичник! мог поставить печь в каком угодно доме. Максим Телятников, сапожник: что шилом кольнет, то и сапоги, что сапоги, то и спасибо $<\ldots>$ Да, конечно, мертвые $<\ldots>$ Впрочем, и то сказать: что из этих людей, которые числятся теперь живущими? Что это за люди? мухи, а не люди <..>

Чичиков попросил списочка крестьян. Собакевич <..> собственноручно принялся выписывать всех не только поименно, но даже с означением похвальных качеств < ..> [Чичиков] < ..> подивился аккуратности и точности: не только было обстоятельно прописано ремесло, звание, лета и семейное состояние, но даже на полях находились особенные отметки насчет поведения, трезвости, - словом, любо было глядеть».

The nostalgic memorial note is trumpeted ironically as Sobakevich, trying to inflate the price, extolls their virtues. Eventually it comes to the actual writing out of the list and commenting on its physical and textual characteristics. Haggling over the dead's professional merits and monetary value transforms a mere list onto a protracted comic scene. Villon.

4. A famous, strictly female list is "The Ballad of the Ladies of Yore" by Francois

François Villon, "Ballade des dames du temps jadis":

Dictes moy ou, n'en quel pays,

Est Flora, la belle Romaine;

Archipiada, ne Thaïs

Qui fut sa cousine germaine;

Echo, parlant quand bruyt on maine

Dessus riviere ou sus estan,

Qui beaulté ot trop plus qu'umaine?

Mais ou sont les neiges d'antan?

Ou est la tres sage Heloÿs,

Pour qui fut chastré et puis moyne

Pierre Esbaillart a Saint Denis?

Pour son amour ot ceste essoyne.

Semblablement, où est la royne

Qui commanda que Buridan

Fust gecté en ung sac en Saine?

Mais ou sont les neiges d'antan?
La royne Blanche comme lis,

Qui chantoit a voix de seraine;

Berte au grant pié, Bietris, Allis;

Haremburgis qui tint le Maine,

Et Jehanne, la bonne Lorraine,

Qu'Englois brulerent a Rouan;

Ou sont ilz, ou, Vierge souveraine?

Mais ou sont les neiges d'antan?

Prince, n'enquerrez de sepmaine

Ou elles sont, ne de cest an,

Qu'a ce reffrain ne vous remaine:

Mais ou sont les neiges d'antan?

François Villon, "The Ballad of Dead Ladies” (transl. D.G. Rossetti):

Tell me now in what hidden way is

Lady Flora the lovely Roman?
Where's Hipparchia, and where is Thais, Neither of them the fairer woman? 
Where is Echo, beheld of no man,

Only heard on river and mere, -

She whose beauty was more than human? ...

But where are the snows of yester-year?

Where's Héloise, the learned nun,

For whose sake Abeillard, I ween,

Lost manhood and put priesthood on?

(From Love he won such dule and teen!)

And where, I pray you, is the Queen

Who willed that Buridan should steer

Sewed in a sack's mouth down the Seine? ...

But where are the snows of yester-year?
White Queen Blanche, like a queen of lilies, With a voice like any mermaiden, Bertha Broadfoot, Beatrice, Alice, And Ermengarde the lady of Maine, And that good Joan whom Englishmen At Rouen doomed and burned her there, Mother of God, where are they then? ... But where are the snows of yester-year?

Nay, never ask this week, fair lord, Where they are gone, nor yet this year, Save with this much for an overword, But where are the snows of yester-year?

This catalog of names associated with legendary stories about love and death basically sticks to the enumerative pattern. To narrativise it at least in part, the poet introduces a series of refrains - rhetorical questions he asks and answers himself (Where...? - Alas, where...?), simulating a sort of a roll call. This involves the reader in interactive participation and enhances the credibility of the discourse, which is delivered in the modest format of shared sorrowful meditation.

The credibility of the list is also certified by the indisputable cultural status of the stories/legends and the social prestige of their heroines (goddesses and queens). As for the note of memorial nostalgia, it naturally emanates from the temporal gap in dealing with figures of a distant past plus the cruelty of the fate that befell them even then. This central theme of martyrdom clearly dominates the rather diverse list.

5. A quite different catalog of women is the so-called Don Juan list that appears in Mozart's Don Giovanni (libretto by Lorenzo da Ponte).

Lorenzo da Ponte, Leporello's “Catalog Aria” from Mozart's Don Giovanni

Madamina, il catalogo è questo

delle belle che amò il padron mio;

un catalogo egli è che ho fatt'io.

Osservate, leggete con me.

In Italia seicento e quaranta,

in Allmagna duecento e trentuna,

cento in Francia, in Turchia novantuna,

ma in Espagna son già mille e tre!

V'han fra queste contadine,

cameriere e cittadine,

v'han contesse, baronesse,

marchesane, principesse,

e v'han donne d'ogni grado,

d'ogni forma, d'ogni età.

Nella bionda egli ha l'usanza di lodar la gentilezza, nella bruna la costanza, nella bianca la dolcezza.

Vuol d'inverno la grassotta, vuol d'estate la magrotta; è la grande maestosa, la piccina è ognor vezzosa ...

Delle vecchie fa conquista per piacer di porle in lista; ma passion predominante è la giovin principiante.

Non si picca se sia ricca, se sia brutta, se sia bella; purché porti la gonnella, voi sapete quel che fa!

"Catalog Aria", transl. from New York City Opera Project: Don Giovanni:

My dear lady, this is a list

Of the beauties my master has loved,

A list which I have compiled.

Observe, read along with me.

In Italy, six hundred and forty;
In Germany, two hundred and thirty-one; A hundred in France; in Turkey, ninety-one; In Spain already one thousand and three. Among these are peasant girls, Maidservants, city girls, 
Countesses, baronesses,

Marchionesses, princesses,

Women of every rank,

Every shape, every age.

With blondes it is his habit

To praise their kindness;

In brunettes, their faithfulness;

In the very blond, their sweetness.

In winter, he likes fat ones.

In summer, he likes thin ones.
He calls the tall ones majestic.

The little ones are always charming.

He seduces the old ones

For the pleasure of adding to the list.

His greatest favorite

Is the young beginner.

It doesn't matter if she's rich,

Ugly or beautiful;

If she wears a petticoat,

You know what he does.

The catalog of the protagonist's amorous conquests is sung by his trusted valet Leporello and addressed to one of the abandoned women, Elvira. In many ways the catalog is quite traditional: it features 5 toponyms and 5 respective numerals, totaling 1865 females, 16 types (peasant girls... a blonde... a plump one... a debutante), and 11 additional features crowned with the most generic twelfth (skirt wearing).

The list is clearly vertical and remarkably includes no proper names (of women) only categories. This plays into the image of Don Juan, who is after sheer numbers and variety as tokens of his power, and lends the structure of the catalog an innovatively impersonal, anonymous character.

The catalog is physically embodied in an impressive text object (questo non picciol libro [this not minuscule book]), compiled by Leporello and shown to Elvira in response to her reproaches. As a result, it is not so much declaimed monologically as enacted dialogically, which is particularly appropriate in a work for the stage.

The list is also animated by its gradually increasing structural complexity. It begins with impersonal numbers, proceeds to social categories of women, then to the types of their assets (like the wintertime advantages of fatties); also mentioned is the protagonist's metatextual care for constantly increasing the length of the list.

The structural development is accompanied by a sequence of three different musical sections of the aria. Joseph Losey, in the film-opera "Don Giovanni" he directed (1979), found a felicitous spatial counterpart to these effects. The mise-en-scene features Leporello and his assistants carrying heavy scrolls which they gradually roll down the steps of castle's wide external staircase. Elvira follows the scrolls, now reading the text, now covering her face in despair.
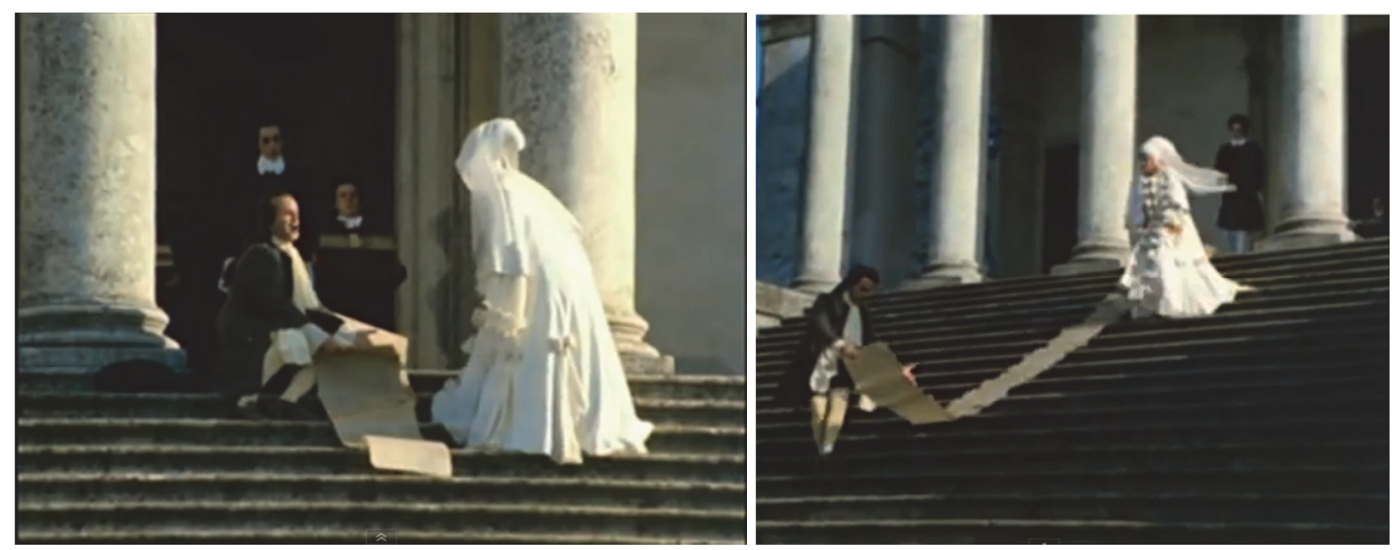
In this way, the dramatic and musical dynamisation of the list is supported by its graphic spatialization.

The Don Juan list has a Homeric prototype: the catalog of the former lovers of Zeus which he includes in his declaration of love for Hera (Iliad, Canto XIV). Her acceptance of this strange courtship is skilfully naturalized — not so much by the list's being strictly virtual (all the affairs are in the past), but above all by the fact that it is Hera that is slyly seducing her husband in order to distract him while Poseidon assists the Achaeans.

6. A Don Juan list narrativized into a short story format underlies the plot of Nabokov’s "Skazka" (1930; "Nursery Tale", 1975).

The protagonist, Erwin, encounters the Devil in the shape of a middle-aged German woman who tells him he can have all the women he can "collect" in a day, provided the number is odd. By midnight he has exactly a dozen, then makes the point of adding the thirteenth only to discover that she is the same as the very first one and so has to admit defeat.

The catalogical skeleton of the story is obvious. It comprises:

- formation of a virtual harem with numeric parameters;

- abundance of numeric objects (a dial with four hands; a street and a streetcar, both involving numbers);

- fixation on other numbers, in particular archetypal ones (a dozen and a baker's/ devil's (chertova) dozen.

Plots based on a gradual unfolding of a list are a common type of narrative. The list can be a set of similar characters (Ten Little Indians by Agatha Christie, "The Darling" by Chekhov) or of similar inanimate objects ("Six Napoleons" by Conan Doyle, The Twelve Chairs by Ilf and Petrov).

7. Next come lists of role models. We can begin with the genre of genealogy, dating back all the way to the epic and biblical tradition, in particular, the Gospel genealogies of Jesus. Pushkin authored two specimens of the genre, Moia rodoslovnaia (My genealogy) and Ezerskii, both saturated with toponyms and names of the protagonist's ancestors and other historical figures.

Then there are the lists of cultural heroes or their works, mostly books, which influenced a literary character.

Pushkin, in his meta sonnet,

Суровый Дант не презирал сонета;

В нем жар любви Петрарка изливал;

Игру его любил творец Макбета;

Им скорбну мысль Камоэнс облекал.

И в наши дни пленяет он поэта:

Вордсворт его орудием избрал,

Когда вдали от суетного света

Природы он рисует идеал.

Под сенью гор Тавриды отдаленной

Певец Литвы в размер его стесненный

Свои мечты мгновенно заключал. 


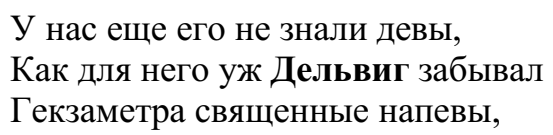

annotated and narrativised a gallery of the genre's classics. Such parading of role models and their key properties/attributes was later parodied in Kozma Prutkov's "Честолюбие" (Дайте силу мне Самсона ... ["Ambition": Give me the strength of Samson ...]).

In the $20^{\text {th }}$ century, the tradition of playing with poets' attributes included, among others:

Mandel'shtam's

«Стихи о русской поэзии» ("Verses about Russian poetry")

«Дайте Тютчеву стрекозу...» (“Give Tiutchev a Dragonfly...”)

and Kushner's:

«Наши поэты» (Конечно, Баратьнский схематичен... [“'Our Poets”: Of course, Baratynsky is schematic...)

«Кто с чем» (Мандельштам приедет с шубой... ['Who [Comes] with What": Mandelstam will come with a fur coat...])

In such catalogs of role models, the poet often reserves a place for him/herself. The motif of joining a coveted circle of greats can be quite modest, as in Kushner's «Мне приснилось, что все мы сидим за столом...» (I Dreamed that We All Sat at the Table...). But it can also be defiantly laid bare, as in

Dmitrii Prigov’s «В Японии я б был Катулл...» (In Japan, I Would be a Catullus...) and «Там, где с птенцом Катулл, со снегирем Державин...» ("Where Catullus is with a Chick and Derzhavin with a Bullfinch...) - in the footsteps of

Khodasevich's «Памяти кота Мурра» (In Memory of Cat Murr).

A classical prototype of such self-promotional catalog poems was of course the episode in Canto IV of the "Inferno", where Dante is accepted as "the sixth among the wise ones," that is, acknowledged as one of their own by Homer, Horace, Ovid, Lucan and Virgil.

A modernist variation on this Dantesque theme yielded, on Russian soil, the format of "There-are-so-many-of-us" (Нас было столько-то) poems.

It was originated by Pasternak’s «Нас мало. Нас, может быть, трое...» (We Are Few. There Are Perhaps Three of Us...). The title line goes back to the words of Pushkin's Mozart: Нас мало избранных, счастливиев праздных (We are few, the chosen lucky idlers), which inaugurated focusing not on the dead classics but on the author's living fellow poets (Pasternak implies the three are himself, Mayakovsky and Aseev). Later Akhmatova came up with a variation: «Нас четверо. Комаровские наброски» (We Are Four. Komarovo sketches), where the other three are Mandel'shtam, Pasternak and Tsvetaeva. This was followed up by Andrei Voznesensky's «Нас много. Нас может быть четверо...» ("We Are Many. There Are Perhaps Four of Us...), referring to Akhmadulina, Yevtushenko and Robert Rozhdestvensky.

The above poems share a characteristic lack of direct naming of the - unlisted names: readers are invited to figure out on their own who belongs to the in-group. Thus, the list is not spelled out but pointedly implied, offering one more variation on the theme of catalog's virtualness. On the contrary, Mayakovsky's «Юбилейное» (The Anniversary Poem), which parodies the most authoritative type of catalog, the encyclopedia, is quite explicit on the subject of naming. 
Александр Сергеевич,

разрешите представиться.

Маяковский $<. .>$

да и разговаривать не хочется

ни с кем.

Только

жабры рифм

топырит учащенно

у таких, как мы,

на поэтическом песке.

Мне приятно с вами, -

рад,

что вы у столика.

Муза это

ловко

за язык вас тянет <..>

Мне

\section{при жизни}

с вами

сговориться б надо <...>

После смерти

нам

стоять почти что рядом:

вы на Пе,

а я

на эМ.

Кто меж нами?

с кем велите знаться?! < ..>

Чересчур

Страна моя

поэтами

нища.

Между нами

— вот беда -

позатесался Надсон.

Мы попросим,

чтоб его

куда-нибудь

на Ща!

А Некрасов

Коля,

сын покойного Алеши, он и в карты,

он и в стих,

и так

неплох на вид.
Знаете его?

Bот OH

мужик хороший.

Этот

нам компания -

Что ж о современниках?!

пускай стоит.

Не просчитались бы,

за вас

полсотни отдав.

От зевоты

скулы

разворачивает аж!

Дорогойченко,

Герасимов,

Кириллов,

Какой

Родов -

однообразный пейзаж!

Ну Есенин,

мужиковствующих свора.

Смех!

Коровою

в перчатках лаечных.

Раз послушаешь...

но это ведь из хора!

Балалаечник! <..>

Ну, а что вот Безыменский?!

Так...

ничего...

морковный кофе.

Правда,

есть

у нас

Aceeв

Колька.

Этот может.

Хватка у него

Моя $<$... $>$

Были б живы -

стали бы

Вы б смогли -

по Лефу соредактор <...>

у вас

хороший слог < ..>

Mayakovsky turns Dante's formula inside out - futurist-style: the poet does not seek approval from the elect, but on the contrary, condescendingly accepts classics such as Pushkin and Nekrasov into the inner circle of his LEF buddies. At the same time, 
a number of "outsiders" are blatantly deleted from the encyclopedia. Thus, Mayakovsky, who started out by tampering with the encyclopedia's alphabetical order, i.e. its verbal aspect, proceeds to revising its backbone - the list of entries (словник).

8. From metaliterary catalogs, let us now move to metalinguistic ones, those that foreground the verbal aspect of the inventory.

Chekhov's «Свадьба с генералом» (“Wedding with a General”) reads like a naval phrasebook.

«- Да-с <..> В старину всё просто было $<\ldots>$

Адмирал $<\ldots>$ увидел молодого гардемарина $<\ldots>$

— Чай, теперь всё <..> не так, как при нас было $<$...> Всякое незначительное слово имеет $<. . .>$ свое таинственное... ээ... недоумение. Например, марсовые к вантам, на фок и грот. Что это значит? Это значит, что < .. > Иначе надо командовать: саленговые к вантам! Тут уж другой смысл <...> А вот ежели: на брамсели и бомбрамсели! Тут марсовые, которые назначены для отдачи марселей и бом-брамселей, что есть духу бегут с марсов на салинги и бом-салинги, потом... дай бог память... расходятся по реям и раскрепляют означенные паруса, а <..> люди, которые внизу, становятся на брам и бом-брам-шкоты, фалы и брасы <..> Мало ли разных команд <... Брам и бом-брам-шкоты тянуть, фалы поднимааай! <..> Потравливают брасы <...> а когда уж < ..> шкоты натянуты и фалы все до места подняты, то брам и бом-брам-брасы вытягиваются и реи брасопятся соответственно направлению ветра...

- Дядюшка! < ... Это непонятно гостям и... скучно.

[Д]ядюшка не унимался. Он выкрикивал команду за командой и <... пояснял длинным комментарием $<\ldots>$

— И ведь все это надо помнить! <..> Вы не понимаете, потому что... термины! <...> А молодой человек понимает... Да. Старину с ним вспомнил <... Пла... плачу... Рад...».

The focus is once again on ships, however, this time not on realia, but on verbal formulas. The text is saturated with terms for sailors' specialized functions, parts of the rigging and respective actions. The sheer quantity of these items is complemented by the density of the professional lexicon, which calls for commentaries, which in turn lead to nonsensical repetitions of the exotic terms. This makes the pile-up of barbarisms even more comic and concentrates attention on the mnemonic and meta-verbal motifs: the ex-admiral emphasizes the need to understand every minor term and remember every command verbatim.

In a sense, we are exposed live to one of those feats of memory that are characteristic of the oral performance of ancient catalog passages. Enhancing the effect is the puzzling - tongue twisting — phonetic similarity of many of the borrowed terms (марсы, марсовые, марсели, брамсели, бом-брамсели, бом-брам-брасы, брасопятся). The theme of memory is treated both comically (as the forgetful old man keeps saying дай Бог память [God grant me memory]), and with touching nostalgia (as he longs for the past: В старину все просто было; Пла... Плачу... Рад [In olden times it was all simple; Cry...crying... Glad]).

9. A plethora of verbal lists is found in Ilf and Petrov, whose interest in catalogs lies at the intersection of their two recurrent motifs: mocking Soviet bureaucratic culture and parodying linguistic clichés. 
The two are often combined, for example, in Polykhayev's universal stamp, which is a materialized set of directives cast in stone - typographic ink, and in the parodic lessons Ostap Bender gives the foreign specialist:

«-Шрайбен, ириб, гешрибен. Писать. Понимаете? <..> Mbl, выl, они, оне пишут жалобы и кладут в сей ящик <...> И никто их не вынимает. Вынимать! Я не вынимаю, тыл не вынимаешь...» [The verb to write, see? <... We, you, they write complaints and put in this box $<\ldots>$ And nobody takes them out. To take out. I do not take out, you do not take out...).

But a metalinguistic list can also be indifferent to the theme of bureaucracy, as, for instance, the 30-word long vocabulary of Ellochka Shchukina.

10. To return to lists of real items, so far we have discussed only lists of persons - military men, lovers, poets. But along with those, texts often feature the heroes' geographical - toponymical - coordinates and surrounding objects: in Homer, ships, horses, fields; in Gogol, coaches, stoves, boots and other products of Sobakevich's dead serfs; in Prutkov, the symbolic attributes of the greats.

A major group of listable objects comprises accessories of everyday human use. A hilarious case is the list of anus-wipers in Rabelais' Gargantua and Pantagruel (Book One, Chapter 13). It features 64 kinds, some just listed, some developed into annotations or even mini-plots, and topped off at the end by the utensil Gargantua finds to be the best: a fluffy gosling. The comic effect is achieved, of course, by a carnivalesque parody of epic catalogs.

A widespread type are loading lists for various transportation vehicles, predominantly ships, of course.

Each of the four parts of Gulliver's Travels begins with the protagonist leaving England and ends with his return, so that, overall, he goes through at least eight major departures. But Jonathan Swift indulges in a loading protocol only once, when Gulliver is to sail home from Blefuscu.

"I stored the boat with the carcasses of a hundred oxen, and three hundred sheep, with bread and drink proportionable, and as much meat ready dressed as four hundred cooks could provide. I took with me six cows and two bulls alive, with as many ewes and rams, intending to carry them into my own country, and propagate the breed. And to feed them on board, I had a good bundle of hay, and a bag of corn. I would gladly have taken a dozen of the natives, but this was a thing the emperor would by no means permit; and, besides a diligent search into my pockets, his majesty engaged my honor "not to carry away any of his subjects, although with their own consent and desire."

Jonathan Swift, Gulliver's Travels into Several Remote Nations of the World (Chapter VIII)

The scale of the list (one hundred... three hundred... four hundred...) is justified by the miniscule size of the cattle (which will help Gulliver to convince his compatriots of the veracity of his story).

A long delay also precedes the appearance of a loading list in Daniel Defoe's Robinson Crusoe. Prior to his main shipwreck, Robinson undertakes several voyages, 
which are not inventoried. It is only in Chapter 6 that a catalog appears, unfolding gradually as Robinson looks for and finds various useful items on board the semi-sunken ship and transfers them onto his raft to take to the island.

"My raft was now strong enough $<\ldots>$ My next care was what to load it with $<\ldots>$ I got three of the seamen's chests, which $\mathrm{I}<\ldots>$ lowered $<\ldots>$ down upon my raft; the first of these I filled with provisions - viz. bread, rice, three Dutch cheeses, five pieces of dried goat's flesh $<\ldots>$ and a little remainder of European corn $<\ldots>$ some barley and wheat $<\ldots>$ As for liquors, I found several cases of bottles $<\ldots>$ and, in all, about five or six gallons of rack $<\ldots>$

The tide beg[a]n to flow $<\ldots>$ and I had the mortification to see my coat, shirt, and waistcoat $<\ldots>$ swim away. As for my breeches $<\ldots>$ I swam on board in them and my stockings $<\ldots>$ I had others things which my eye was more upon - as, first, tools to work with $<\ldots>$ After long searching $<\ldots>$ I found out the carpenter's chest $<\ldots>$

My next care was for some ammunition and arms. There were two very good fowlingpieces in the great cabin, and two pistols. These I secured first, with some powder-horns and a small bag of shot, and two old rusty swords $<\ldots>$ There were three barrels of powder $<\ldots$. two of them dry $<\ldots>$ the third had taken water $<\ldots .>$ And now I thought myself pretty well freighted $<\ldots>$ and began to think how I should get to shore with them".

Both ship lists are pointedly borderline - and thus smack of virtuality — as they hover between the worlds of the Lilliputians and Robinson's compatriots, the ship and the uninhabited island, presence and absence, life and death, reality and fiction.

A list of items to be transported by train appears — as a refrain with variations in Samuil Marshak's poem «Багаж» (Baggage):

Дама сдавала в багаж

Диван,

Чемодан,

Саквояж,

Картину,

Корзину,

Картонку

И маленькую собачонку.

Выдали даме на станции

Четыре зеленых квитанции

О том, что получен багаж:

Диван,

Чемодан,

Саквояж,

Картина,

Корзина,

Картонка

И маленькая собачонка.

Вещи везут на перрон.

Кидают в открытый вагон.
Готово. Уложен багаж:

Диван,

Чемодан,

Саквояж,

Картина,

Корзина,

Картонка

И маленькая собачонка.

Но только раздался звонок,

Удрал из вагона щенок.

Хватились на станции Дно:

Потеряно место одно.

В испуге считают багаж:

Диван,

Чемодан,

Саквояж,

Картина,

Корзина,

Картонка...

— Товарищи! Где собачонка? 
Вдруг видят: стоит у колес

Огромный взъерошенный пес.

Поймали его - и в багаж,

Туда, где лежал саквояж,

Картина,

Корзина,

Картонка,

Где прежде была собачонка.

Приехали в город Житомир.

Носильщик пятнадцатый номер

Везет на тележке багаж:

Диван,

Чемодан,

Саквояж,

Картину,

Корзину,

Картонку,

А сзади ведут собачонку.

Собака-то как зарычит,

А барыня как закричит:

- Разбойники! Воры! Уроды!
Собака - не той породы!

Швырнула она чемодан,

Ногой отпихнула диван,

Картину,

Корзину,

Картонку...

- Отдайте мою собачонку!

- Позвольте, мамаша! На станции,

Согласно багажной квитанции,

От вас получили багаж:

Диван,

Чемодан,

Саквояж,

Картину,

Корзину,

Картонку

И маленькую собачонку.

Однако

За время пути

Собака

Могла подрасти!

One item — the only animate one, a little doggie concluding the list, — disappears in the course of the voyage and is replaced with a different one. This enlivens the narrative and prompts the introduction of a nostalgic, Villon-like rhetorical question: - Tоварищи! Где собачонка? (- Comrades, where is the doggie?).

One of the earliest loading catalogs was, of course, the list of persons and animals to be saved on Noah's ark, which recurs six times, with variations, in the Book of Genesis, chapters $6-8$, as God formulates and repeats his instructions to Noah, who then is reported to carry them out $(6.18-20,7: 1-3,7-9,13-16,8: 15-17$, $18-19)$. Here is the first of these fragments, but the next time the list appears (in the beginning of Chapter 7) the numbers are modified.

Genesis, 6. 18-20:

18. ... and thou shalt come into the ark, thou, and thy sons, and thy wife, and thy sons' wives with thee.

19. And of every living thing of all flesh, two of every sort shalt thou bring into the ark, to keep them alive with thee; they shall be male and female.

20. Of fowls after their kind, and of cattle after their kind, of every creeping thing of the earth after his kind, two of every sort shall come unto thee, to keep them alive.

Genesis, 7: 2-3:

2. Of every clean beast thou shalt take to thee by sevens, the male and his female: and of beasts that are not clean by two, the male and his female.

3. Of fowls also of the air by sevens, the male and the female; to keep seed alive upon the face of all the earth.

Overall, the list is rather abstract: even the members of Noah's family are not named personally, but referred to by their terms of kinship. And the animals are mentioned only at the level of classes, not particular species; most prominent are numerals (twos and sevens). 
11. Another traditional type of catalog is a list of goods offered/ordered as a purchase, gift, ransom. Such lists are usually presented and repeated only to be rejected.

Sometimes the order itself begins with a formulaic rejection, as, for instance, in Sergei Aksakov's «Аленький цветочек» (The Scarlet Flower), where, incidentally, the coveted objects are заморские, from overseas. First, the oldest sister rejects a standard set of gifts, and then each of the younger ones in succession rejects the previous sister's list and offers her own.

The motif of a gift/ransom list also goes back to the Iliad, Canto IX, where Agamemnon decides to appease Achilles with gifts. He sends him a list of them with Odysseus, but Achilles rejects it. Agamemnon's list boasts many of the typical parameters of a catalog: the verb "to count, enumerate", and several numerals; toponyms and other proper names; a ship to carry the stuff. Compared to most later gift lists, this one dazzles by including women (among them not only the future Trojan captives but also some of Agamemnon's own daughters) and entire cities.

Literary catalogs can also use as their sources other types of registers: train schedules, passenger lists, library catalogs, restaurant menus, class registers etc.

12. As far as menus are concerned, worth mentioning are:

Eugene Onegin's Chapter One, stanza XIV, flaunting chic barbarisms:

К Talon ${ }^{4}$ помчался: он уверен,

Что там уж ждет его Каверин.

Вошел: и пробка в потолок,

Вина кометы брызнул ток,

Пред ним roast-beef окровавленный,
И трюфли, роскошь юных лет, Французской кухни лучший цвет,

И Стразбурга пирог нетленный Меж сыром Лимбургским живым И ананасом золотым.

and the episode of Sasha Sokolov's Palisandria/Astrophobia where the title narratorprotagonist reports having had dinner with Samuel Beckett and pastes into the text a full menu in Danish, without translation or comments, - in an in-your-face laying bare of the catalog technique.

\section{MENU}

Forretter:

Klar Suppe med Kød og Melboller $12.50 \mathrm{kr}$

Hønsesuppe med Aspares $13.75 \mathrm{kr}$

Hovedretter:

Medisterpølse med Kartofler, sovs og Rødbeder $18.50 \mathrm{kr}$

Frikadeller med sovs, Kartofler og Rødkal $20.50 \mathrm{kr}$

Boller i Karry med Ris $16.50 \mathrm{kr}$

Wienerschnitzel med sovs, Kartofler og Grøntsager $22.50 \mathrm{kr}$

Dansk Bøf med Kartofler, sovs, Bønner og Bløde Løg $25.00 \mathrm{kr}$

Efterretter:

Vanilleis med Chokoladecreme $8.50 \mathrm{kr}$.

Fromage med Karamelsauce og Sukater $12.50 \mathrm{kr}$ 2 Pandekager med Hjemmelavet Syltetøj $10.50 \mathrm{kr}$ 
The class list format was used by Nabokov in Lolita (I, 11). Humbert Humbert discovers Lolita's class list on the back of a USA map (a bow to the geographical motif) and engages in a close reading of this poem, its semitranslucent mystery and the semantic and onomastic connotations of a dozen of the forty names. Nabokov succeeded in provoking a prolific industry of scholarly commentaries to the list, impressive, but of course not authorized, thus creating an additional virtual counterpoint to the quasi-documentary register.

13. In Soviet literature, the virtual aspect of catalogs gained a new poignancy owing to a sweeping loss of cultural wealth and creature comforts in the course and aftermath of the Bolshevik revolution. An early example of a list of losses was Mikhail Kuzmin's 1922 poem «,А это - хулиганская“, — сказала...» (And this one is a hooligan's, - she said...). In it, the poet recalls with bittersweet nostalgia a number of pre-revolutionary realities. The poem features: a set of Russian imperial toponyms; memories of the past; a collector's taste for the names of objects; and an embodied catalog (Страницы из «Всего Петербурга» ... за 1913 год [Pages from 'All of Petersburg' [a phone directory]... for the year 1913]).

A similar case is the inventory of Vorobianinov's chairs and other such lists which are physically there in the form of opdepa (orders) accumulated by the registrar Korobeinikov in Ilf and Petrov's Twelve Chairs (1927). Prominent is also the element of meta-verbal attention to exotic names, naturalized by the alphabetical structure of the archive:

«- Есть буква $B,-$ охотно отозвался Коробейников. - Сейчас. $B$ м, Bн, Ворицкий <..> Воробьянинов, Ипполит Матвеевич» (- Here is letter V, - willingly responded Korobeinikov. — VM, Vn, Voritsky... Vorobyaninov, Ippolit Matveevich).

Four years later a list of vanished, scarce, defitsitnyi values informs Mandel'shtam poem

Я пью за военные астры, за все, чем корили меня:

За барскую шубу, за астму, за желчь петербургского дня.

За музыку сосен савойских, Полей Елисейских бензин, За розы в кабине рольс-ройса и масло парижских картин.

Я пью за бискайские волны, за сливок альпийских кувшин, За рыжую спесь англичанок и дальних колоний хинин,

Я пью, но еще не придумал — из двух выбираю одно -

Душистое асти-спуманте иль папского замка вино...

Cataloging is prompted by the poet's invariant motifs of separation from and longing for world values, their obsessive contemplation and mental leafing through. The nostalgic theme finds an ingenious expression in a pointed demarcation of borders: historical (as at first, in the footsteps of Kuzmin, the values listed are pre-revolutionary) and then geographical (the list that follows is of foreign values).

Nostalgic collectors of pre-revolutionary artefacts are at the center of the novels of Konstantin Vaginov, beginning with his 1928 Kozlinaia pesn' (The Goat Song). Their collections and catalogs are desperately virtual, as the men are bent on preserving such 
evanescent values as old-time culinary recipes or completely ephemeral objects like dreams or scraps of human nails; sometimes the men themselves disdain their bizarre collections.

A likely classic prototype of such catalogs of losses was the list of Peter Grinev's stolen belongings submitted to Pugachev by Savel'ich.

«В это время <...> вижу <...> мой Савельич подходит к Пугачеву и подает ему лист бумаги $<\ldots>$ - Это что? - спросил важно Пугачев. - Прочитай, так изводишь увидеть $<\ldots>$

Пугачев принял бумагу и долго рассматривал с видом значительным. - Что ты так мудрено пишешь? < ..> Наши светлые очи не могут тут ничего разобрать. Где мой обер-секретарь? <...> Читай вслух <..>

Я чрезвычайно любопытствовал узнать, о чем дядька мой вздумал писать Пугачеву. Обер-секретарь <..> стал по складам читать следующее: - Два халата, миткалевый и шелковый полосатый, на шесть рублей. - Это что значит? сказал, нахмурясь, Пугачев. - Прикажи читать далее, - отвечал спокойно Савельич <... - Мундир из тонкого зеленого сукна на семь рублей. Штаны белые суконные на пять рублей. Двенадцать рубах полотняных голландских с манжетами $<$.. $>$ Погребец с чайною посудою $<\ldots>$

— Это, батюшка $<$...> реестр барскому добру, раскраденному злодеями... Какими злодеями? - спросил грозно Пугачев. - Виноват <...> Злодеи не злодеи, а твои ребята $<\ldots>>$ порастаскали < ... Прикажи уж дочитать. - Дочитывай $<$...> - Одеяло ситцевое, другое тафтяное на хлопчатой бумаге четыре рубля. Шуба лисья, крытая алым ратином, 40 рублей. Еще заячий тулупчик, пожалованный твоей милости $<$... 15 рублей.

— Это что еще! <...> - вскричал [Пугачев], выхватя бумагу из рук секретаря и бросив ее в лицо Савельичу <...> Заячий тулуп! <..> Да <..> я с тебя живого кожу велю содрать на тулупы <...>

[Но] Пугачев был, видно, в припадке великодушия <... Я остался на площади один с Савельичем. Дядька мой держал в руках свой реестр <..> - Смейся, сударь, <...> смейся; а как придется нам сызнова заводиться всем хозяйством, так посмотрим, смешно ли будет».

The episode boasts a number of rhetorical effects: a defamiliarized perception of its unfolding by Grinev the narrator; the handing over of an actual list; the twists and turns of its reading (featuring manifestations of Pugachev's thinly disguised illiteracy); and, to top it off, the inclusion of the famous hare skin coat, which was given to Pugachev, not stolen by his underlings, thus firmly rooting Savel'ich's petition in the core plot of The Captain's Daughter. Its ironic invoice style -

"Two dressing gowns, one cotton, the other striped silk, six roubles... One uniform of fine green cloth, seven roubles; one pair trousers, white cloth, five roubles; twelve shirts of Holland shirting, with cuffs, ten roubles; one box with tea service, two-and-a-half roubles..."

(Pushkin, The Daughter of the Commandant, transl. Mrs. Milne Home)

— is pressed in the service of portraying irrevocable losses in the midst of a social upheaval. 
14. The theme of defitsit, or manmade scarcity, flourished in the dissident literature of the so-called period of Soviet stagnation. By combining two extant catalog formats, the nostalgic and the trade/gift ones, often with an "overseas" flavor, the popular motif of an order for a supply of imported goods (списка-заказа на привоз дефицитных товаров) was created.

Vladimir Vysotsky, the dissident bard, has a song titled "A Trip to the City" («Поездка в город», 1969; listen on-line http://www.youtube.com/watch?v=4wTOlj15WDw):

Я самый непьющий из всех мужиков, Во мне есть моральная сила.

И наша семья большинством голосов

Снабдив меня списком на восемь листов,

В столицу меня снарядила,

Чтобы я привез снохе

С ейным мужем по дохе,

Чтобы брату с бабой — кофе растворимый,

Двум невесткам по ковру,

Зятю черную икру,

Тестю - что-нибудь армянского разлива.

Я ранен, контужен, я малость боюсь

Забыть, что кому по порядку.

Я список вещей заучил наизусть,

А деньги зашил за подкладку.

Ну, значит, брату - две дохи,

Сестрин муж, - ему духи,

Тесть сказал: - Давай бери, что попадется!

Двум невесткам по ковру,

Зятю беличью икру,

Куму водки литра два, — пускай зальется.

Я тыкался в спины, блуждал по ногам,

Шел грудью к плащам и рубахам,

Чтоб список вещей не достался врагам,

Его проглотил я без страха.
Но помню: шубу просит брат,

Куму с бабой - все подряд,

Тестю - водки ереванского разлива,

Двум невесткам взять махру,

Зятю заячью нору,

А сестре - плевать чего, но чтоб красиво.

Да что ж мне, пустым возвращаться назад?

Но вот я набрел на товары.

— Какая валюта у вас? - говорят.

— Не бойсь, — говорю, — не доллары!

Так что, отвали мне ты махры,

Зять подохнет без икры,

Тестю, мол, даешь духи для опохмелки, Двум невесткам - все равно,

Мужу сестрину — вино,

Ну, а мне, — вот это желтое в тарелке.

Не помню про фунты, про стерлинги слов,

Сраженный ужасной догадкой.

Зачем я тогда проливал свою кровь,

Зачем ел тот список на восемь листов,

Зачем мне рубли за подкладкой?

Все же надо взять доху,

Зятю кофе на меху,

Куму - хрен, а тесть и пивом обойдется,

Также взять коньяк в пуху,

Растворимую сноху,

Ну а брат и самогоном перебьется.

It tells the story of a redneck whose extended family entrusts him with buying all possible kinds of scarce goods while on his trip to the city. The list is physically there, on paper, he memorizes it by heart and later on swallows it "guerrilla"-style in order to avoid detection by the imaginary enemy — and soon to forget it — in a variation on the themes of memory, virtualness, and nostalgia. Structurally, the text recalls Marshak's "Baggage", especially as the variations in the refrain lead to a gradual garbling of the list.

In fact, Vysotsky goes much further, as he keeps slightly rearranging the items. Instrumental in this is the tripartite structure of the item descriptions ("what kind of object" _ "with what specific properties" _ "for which family member"); the three positions have only to be scrambled. As a result, superimposing, for instance, item: зятю черную икру (for the son-in-law black caviar) onto: брату с бабой - кофе раствори- 
мый (for the brother and his woman instant coffee) and onto: снохе С ейным мужем no doxe (to the daughter-in-law and her husband each a deer fur-coat) yields the completely absurd: зятю кофе на меху (for the son-in-law coffee with fur lining).

Indeed, the phonetic similarity of many of the keywords predisposes to such confusion, which is reminiscent of the tongue-twisting pile-up of naval terms in Chekhov's "Wedding with a General". In a sense, Vysotsky's move is doubly innovative: the nostalgic yearning for the scarce values is exacerbated by the destruction and forgetting of the list itself. Meanwhile the rearrangement of the list's components pushes the play with textuality to the point of absurdity, in a nod to the mnemonic challenges faced by the ancient bards. But then, Vysotsky is a modern-day bard.

Chronologically even closer to Luchnikov's list was the defitsitnyi list in Evgeny Yevtushenko's 1977 narrative poem Северная надбавка (The Northern Mark-Up). It has a list of orders that the protagonist in the end refuses to fulfill, deciding to give the whole pile of easy money to his struggling sister and her husband who need a better apartment. His decision is inspired by exclusively noble motives, and dubious Western references (such as the "Beryozka" hard-currency store, the dollars and pounds sterling in the Vysotsky song) are completely absent from the text.

15. It is time to return to Aksenov - and start with his general love of catalogs.

In Затоваренная бочкотара (1968; Surplussed Barrelware), there is first and foremost the list of all the places, persons and things Haligaliyan that Vadim Drozhzhinin the expert knows only from afar. And then, of course, there is also a ship being loaded with humanitarian assistance for Haligaliya, prompting a register of goods:

«- Короче, Вадик, был я там <...> В шестьдесят четвертом году <...> оформился плотником на теплоход „Баскунчак“, а его в Халигалию погнали, понял?

— Это было единственное европейское судно, посетившее Халигалию за последние сорок лет, - прошептал Вадим Афанасьевич.

— Точно, - подтвердил Володя. - Мы им помощь везли по случаю землетрясения.

- Правильно, - еле слышно прошептал Вадим Афанасьевич, его начинало колотить неслыханное возбуждение. - А не помните ли, что конкретно вы везли?

- Да там много чего было - медикамент, бинты, детские игрушки, сгушенки, хоть залейся, всякого добра впрок на три землетрясения и четыре картины художника Каленкина для больниц.

Вадим Афанасьевич с удивительной яркостью вспомнил счастливые минуты погрузки этих огромных, добротно сколоченных картин, вспомнил массовое ликование на причале по мере исчезновения этих картин в трюмах „Баскунчака“».

The most dramatic turn of events in that plotline is the coming true of Drozhzhinin's platonic dream-lists in the real life of Volod'ka Teleskopov, who actually lands in Haligaliya, personally meets all of Drozhzhinin's pen pals and even gets to have sex with Sylvia Chesterton, inaccessible to Drozhzhinin.

«- Да ничего особенного, - махнул ручкой Володя. - Стою я раз в Пуэрто, очень скучаю <...>. Смотрю, симпатичный гражданин идет, познакомились Мигель Маринадо. Потом еще один работяга появляется, Хосе-Луис...

— Велосипедчик? - задохнулся Дрожжинин. 
- Он. Завязали дружбу на троих, потом повторили. Пошли к Мигелю в гости, и сразу девчонок сбежалась куча поглазеть на меня, как будто я павлин кавказский из Мурманского зоопарка <...>

- Кто же там был из девушек? - трепетал Вадим Афанасьевич.

- Сонька Маринадова была, дочка Мигеля <...>, затем, значит, Маришка Рохо и Сильвия, фамилии не помню, ну а потом Хосе-Луис на велосипеде за своей невестой съездил, за Роситой. <..> Ну, Вадик, ты пойми <..> я же не железный, верно? Влюбился начисто в Сильвию, а она в меня».

Thus, a spectacular narrativization is combined with the nostalgic component of the catalog discourse - in its Soviet version.

The fantastic "island" of Crimea never conquered by the Bolsheviks is, in terms of Mandel'shtam's demarcation contours, a two-in-one package: a place that is both pre-revolutionary and foreign. Luchnikov's list comes up as he realizes, in Paris and about to fly to Moscow, that he has bought none of the things unavailable over there (ничего не купил из того, чего там нет!), thus articulating precisely an order for overseas defitsit (заказ на заморский дефицит), and a still-born one, because of his forgetfulness, as well.

The list that follows (see in the beginning of the paper) is pointedly long, syntactically monotonous, strictly matter-of-fact, as it were, rhetorically modest; Aksenov clearly refrains from the playful relishing of details overdone by Yevtushenko. But he saturates his list with borrowed, markedly foreign words, such as:

мини-фото, джинсы, ангора, кашмир, алка зельцер, «скоч», виски, тоник, джина, вермута, «паркер», «монблан», кассета, диктофон, специи, тампекс, менструации, фломастеры, hi-fi, презервативы, вакцина, «Монополь», реостаты, «поляроид», кассетник, STR, баллоны, пьезокристалл, «кварц», галогенный, «Vogue», «Playboy», «Downbeat»,

showning how little has changed since Pushkin's complaint: Но панталоны, фрак, жилет - Всех этих слов на русском нет (... none of these words exist in Russian).

Only occasionally does he interrupt his enumeration with emotional outbursts and repetitions of especially endearing denominations or punctuates it with dry humor:

- джинсов - о, Боже! - вечное советское заклятье - джинсы!

- лака для ногтей и смывки, смывки для лака - ведь сколько уже подчеркивалось насчет смывки!

— клеенки для ванны — с колечками!

- замши, замши...

- липкой ленты «скоч», да и виски «скоч»;

- противозачаточных пилюль и детского питания, презервативов и сосок для грудных.

The list does not pretend to narrativity, but on the contrary sticks to factual itemizing, and in this way it lays bare its textuality, being, as it is, a list of words as much as a list of objects. All the same, the overriding theme of defitsit is omnipresent.

To conclude, Luchnikov's list, as ostensibly matter-of-fact as Lolita's class register, feigns imitating serious catalogs like Homer's or Robinson Crusoe's, but does so playfully, à la Gargantua, lovingly threading exotic barbarisms in the spirit of Chekhov's 
ex-admiral and Onegin's and Palisander's menus, Ilf and Petrov's meta-textuality and mock bureaucratese, of Kuzmin and Mandel'shtam's poignant nostalgia and Vysotsky's and Yevtushenko's orders for zamorskii defitsit.

(C) Alexander Zholkovsky, 2018

\section{REFERENCES}

Aksenov, Vasilii (1981). Ostrov Krym. Ann Arbor, Michigan: Ardis. (In Russ.)

Yampol'skii, Mikhail. 2013. Prostranstvennaya istoriya. Tri teksta ob istorii. SPb.: Seans. (In Russ.)

Minchin, Elizabeth (1996). The Performance of Lists and Catalogs in the Homeric Epics. In Ian Worthington (ed.) Voice into Text: Orality and Literacy in Ancient Greece. Leiden: E.J. Brill, $3-20$.

Shvabrin, Stanislav (2011). "The Burden of Memory": Mikhail Kuzmin as Catalog Poet. In Lada Panova (ed.) The Many Facets of Mikhail Kuzmin: A Miscellany. Bloomington, Ind.: Slavica, $3-25$.

\section{For citation:}

Zholkovsky, Alexander (2018). Listomania, or Catalog as Technique (with Examples from Poetry and Prose, Classical and Modern, Western and Russian). Russian Journal of Linguistics, 22 (4), 945-965. doi 10.22363/2312-9182-2018-22-4-945-965.

\section{Для цитирования:}

Zholkovsky, Alexander (2018). Listomania, or Catalog as Technique (with Examples from Poetry and Prose, Classical and Modern, Western and Russian) // Вестник Российского университета дружбы народов. Серия: Лингвистика $=$ Russian Journal of Linguistics. 2018. Т. 22. № 4. С. 945-965. doi 10.22363/2312-9182-2018-22-4-945-965.

\section{Bionote:}

ALEXANDER ZHOLKOVSKY (b. 1937; Moscow) has taught at Cornell University (1980-1983) and is a Professor of Slavic Languages and Literatures and Comparative Literature (USC, Los Angeles). A graduate of MGU (1959), he holds a PhD in African linguistics (1970) and has published on linguistic theory (in collaboration with Professor Igor Mel'chuk) and on Russian literature and literary theory (partly in co-authorship with Professor Yurii Shcheglov). He is the author of 30 books, some 300 scholarly articles and several collections of fiction and memoiristic prose. Among his latest books: Futile Perfections and Other Vignettes (Moscow, 2015) and Selected Passages, or Miscellaneous Plots (Moscow, 2016).

Contact information: Website: https://dornsife.usc.edu/alexander-zholkovsky/

e-mail: alik@usc.edu

\section{Информация об авторе:}

ЖОЛКОВСКИЙ АЛЕКСАНДР КОНСТАНТИНОВИЧ (р. 1937; Москва) - филолог, прозаик. Окончил филфак МГУ (1959), работал в области структурной и компьютерной лингвистики (с И.А. Мельчуком) и африканистики (язык сомали). Эмигрировал (1979), профессор Корнелльского Университета (1980-1983) и Университета Южной Калифорнии (1983-). Автор трех десятков книг и трех сотен статей по литературоведению (в том числе в соавторстве с Ю.К. Щегловым) и нескольких сборников мемуарных виньеток. Среди последних книг: Напрасные совершенства и другие виньетки (М.: АСТ, 2015) и Выбранные места, или Сюжеты разных лет (М.: КоЛибри, 2016).

Contact information: Website: https://dornsife.usc.edu/alexander-zholkovsky/

e-mail: alik@usc.edu 